\title{
Notes on epilithic, epigeic and muscicolous lichens and lichenicolous fungi from rock outcrops in the mountains of northern Greece
}

\section{Steen N. Christensen ${ }^{1 *} \&$ Vagn Alstrup ${ }^{2}$}

\author{
${ }^{1}$ Københavns Universitet, Statens Naturhistoriske Museum, Botanisk Have og Museum, Gothersgade 130, \\ DK-1123 København K, Denmark \\ ${ }^{2}$ Dalkær 9.2, DK-2605 Brøndby, Denmark
}

Received 13 November 2012 / Accepted 21 December 2012 / Published 11 January 2013

Christensen, S.N. \& Alstrup, V. 2013. Notes on epilithic, epigeic and muscicolous lichens and lichenicolous fungi from rock outcrops in the mountains of northern Greece. - Mycobiota 1: 25-50. doi: 10.12664/ mycobiota.2013.01.04

\begin{abstract}
Of the 154 taxa reported, 27 species are new to Greece, 9 new to the Greek mainland and 39 new to one or more provinces. Many of these records represent substantial range extensions of species with Central European or arctic-boreal distribution. The distribution data are briefly discussed and notes are given on the species composition of different substrates.
\end{abstract}

Key words: biodiversity, granite, Greece, limestone, Mediterranean-montane lichens, serpentine

\section{Introduction}

With the exception of Mt Olimbos (= Olympos) and the mountains of the Athos peninsula, the high mountains of central and northern Greece are largely neglected by collectors of lichens. However, the Pindos range and other mountains of northern Greece harbour a rich and interesting lichen biota of relevance to European biodiversity and plant geography (Christensen \& Svane 2009). This paper reports lichens and lichenicolous fungi collected on rocky outcrops and grassland of the mountains of northern Greece. Save for lichens from openings in woodlands, only specimens from non-forested habitats are included.

This paper reports a number of lichens new to Greece or parts thereof. It also comments on lichens with noteworthy range extensions. Finally, as knowledge of the substrate and other ecological parameters of the lichens of northern Greece is meagre, species lists from different substrates and different altitudes are presented.

*Corresponding author: e-mail: steenc@snm.ku.dk 


\section{Materials and methods}

Except for specimens from localities 3 and 4, all the specimens were collected by the first author. Specimens collected in 1977 and 1978 were not numbered in the field. They are given arbitrary reference numbers initiated by GR. With some exceptions the second author determined the non-lobate crustose epilithic specimens and lichenicolous fungi collected in 1977 and 1978 while the first author determined most of the remainder of the specimens. The nomenclature is in accordance with Abbott (2009). Thus, for example, the Lecanora muralis group is not treated as Protoparmeliopsis and Neofuscelia is kept separate from Xanthoparmelia. When, in a few cases, other synonyms are used, those used by Abbott (2009) are also given. Whenever specimens are labelled with older synonyms these are included. The Greek distribution of the species was checked against Abbott (2009). *** denominates new to Greece, ${ }^{* *}-$ new to the mainland of Greece and ${ }^{*}-$ new to one or more provinces.

The specimens collected originate from the 30 localities given below. The locality numbers are given in the 'List of taxa' in brackets, preceding the corresponding collection numbers or reference numbers. Where the substrate is given as limestone, hard limestone is referred to, probably including dolomite. The metamorphic limestone rock wall at loc. 1 is referred to as marble, but is probably a calc-silicate rock (see discussion). Serpentine is used as a common name for the different ultramafic rock types as traditionally done in botanical literature.

Names of provinces and larger landscapes follow The Times Atlas of the World (1990). Geographical names for northern Makedhonia and Sterea Ellas follow Greece. Mainland (without Trace) with Crete and Rhodes, 1:500000 (Kümmerly + Frey, Bern Edition 1988). Names for southernmost Makedhonia, Ipiros and Thessalia follow Epiros/Thessaly, 1:250000 (ROAD Editions, Athens 1995). In the field the nomos maps of the Ethniki Statistiki Ypiresia tis Ellados (National Statistical Office of Greece) were used.

The latitudes and longitudes given below are map readings.

To distinguish between the Greek province and the Former Yugoslavian Republic of Macedonia (F.Y.R.O.M.) the former is referred to as Makedhonia and the latter as Macedonia.

\section{Ipiros (= Epiros, Epirus), nomos Ioanninon, North Pindos mountain range}

1 Grammos Mts, E of the village of Aetomilitsa, above the marble quarry on the W slope of the summit Epano Arena. Fagus sylvatica woodland. E facing, vertical limestone rock wall, above the level of the canopy. The metamorphosed limestone (marble) contains siliceous rock fragments. It is probably a calc-silicate rock as mentioned in the discussion. In the species list referred to as marble. 23 Jul 1977. $40^{\circ} 21^{\prime} \mathrm{N}, 20^{\circ} 58^{\prime} \mathrm{E}$.

2 Grammos Mts, E of the village of Aetomilitsa, above the marble quarry on the W slope of the summit Epano Arena. N facing grassland above the Fagus sylvatica woodland. Bedrock: limestone. 23 Jul 1977. $40^{\circ} 21^{\prime} \mathrm{N}, 20^{\circ} 58^{\prime} \mathrm{E}$.

3 Grammos Mts, E of the village of Aetomilitsa, above the marble quarry on the W slope of the summit Epano Arena. Subalpine grassland. Bedrock: limestone. Alt.: 2000-2200 m. 19 Jul 1977. Leg.: Mogens Bohl Pedersen. 40²1’ N, 2058’ E. 
4 As loc. 3, but summit area, $2400 \mathrm{~m}$ alt.

5 Between Mt Smolikas and Mt Trapezitsa, along the Konitsa-Pades road, few km W of the village of Elefthero. Mountain slopes with Abies boresii-regis-Pinus nigra woodland, with elements of Fagus silvatica, Acer and Carpinus, mixed with patches of cultivated land. Road cutting in $\mathrm{N}$ slope, incl. $70^{\circ}$. Schistose rock (clay shale?). Alt. 1135 m. 24 Jul $1994.40^{\circ} 06^{\prime}$ N, $20^{\circ} 53^{\prime}$ E.

6 Mt Smolikas, at lake Drakolimni. Subalpine Festuca grassland, heavily grazed by sheep and goats. On serpentine boulders on $\mathrm{N}$ facing slope, facing the lake. Alt. $2150 \mathrm{~m} .11 \& 12 \mathrm{Jul} 1977.40^{\circ} 07^{\prime} \mathrm{N}$, $21^{\circ} 00^{\prime} \mathrm{E}$.

7 Mt Smolikas, at lake Drakolimni. Subalpine Festuca grassland, heavily grazed by sheep and goats. Bird manured metamorphosed limestone boulders on $\mathrm{N}$ facing slope $S$ of the lake. Alt. $2150 \mathrm{~m} .12 \mathrm{Jul}$ 1977. $40^{\circ} 07^{\prime} \mathrm{N}, 21^{\circ} 00^{\prime} \mathrm{E}$.

8 Mt Smolikas, N of lake Drakolimni. Subalpine Festuca grassland with serpentine boulders and outcrops on $S$ facing mountain slope. Alt. $2150 \mathrm{~m} .12 \mathrm{Jul} 1977.40^{\circ} 07^{\prime} \mathrm{N}, 21^{\circ} 00^{\prime} \mathrm{E}$.

9 Mt Smolikas. Alpine grassland with serpentine boulders and outcrops on $\mathrm{S}$ facing mountain slope. Alt. 2200 m. 13 Jul $1977.40^{\circ} 06^{\prime} \mathrm{N}, 21^{\circ} 01^{\prime} \mathrm{E}$.

$10 \mathrm{Mt}$ Smolikas, below summit. Alpine grassland with serpentine boulders and outcrops on W facing

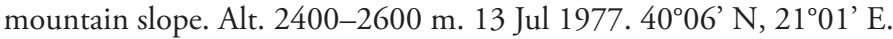

11 Mt Smolikas, summit. Alpine grassland with serpentine boulders and outcrops. Alt. 2600-2650 m. 13 Jul 1977. $40^{\circ} 06^{\prime} \mathrm{N}, 21^{\circ} 01^{\prime} \mathrm{E}$.

12 The Vikos Gorge of river Voidomatis, at the village of Monodendri. Open un-even aged stand of Acer on NE slope of the gorge, incl. $70^{\circ}$. Bedrock: limestone. Alt.: 1025 m. 23 Jul 1994. 3954' N, $20^{\circ} 48^{\prime} \mathrm{E}$.

13 About $18 \mathrm{~km}$ WSW of the town of Ioannina, Mt Kourenton, above the village of Psina. Limestone outcrops in phrygana browsed by sheep. Alt. 1000 m. 4 Sep 1987. 39³7’ N, 2042’ E.

14 Along the Ioannina-Metsovo road, few km W of the village of Mega Peristeri. Open Quercus cocciferaJuniperus oxycedrus thicket on E slope. Bedrock: schistose limestone. Alt.: 600 m. 22 Sep 2002. 3944' $\mathrm{N}, 21^{\circ} 05^{\prime} \mathrm{E}$.

\section{Makedhonia, nomos Grevenon, North Pindos mountain range}

15 About $9 \mathrm{~km}$ E of the village of Samarina, $3 \mathrm{~km}$ SE of Mt Skúrtza, Mt Tampúri. Limestone outcrops on S slope and a N facing rock wall. Alt. 1640-1660 m. 9 Sep 1987. $40^{\circ} 07^{\prime} \mathrm{N}, 21^{\circ} 11^{\prime} \mathrm{E}$.

16 Lingos Range, about $28 \mathrm{~km} \mathrm{NNW}$ of the town of Metsovon, about $2 \mathrm{~km} \mathrm{NW}$ of the village of Avdella, S slope of Mt Vasilitsa. Opening in Fagus forest. Bedrock: serpentine. Alt.: 1550 m. 16 Jul 1978. $40^{\circ} 03^{\prime} \mathrm{N}, 21^{\circ} 09^{\prime} \mathrm{E}$.

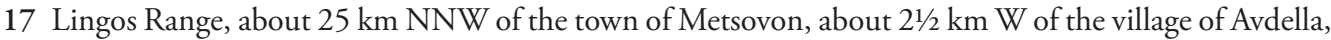
S of Mt Vasilitsa, the ridge Koleo. Plateau with scattered Pinus heldreichii. Bedrock: serpentine. Alt.: 1860 m. 12 Jul $1978.40^{\circ} 01^{\prime}$, N 2109’ E.

18 Lingos Range, about 20 km NNW of the town of Metsovon, Mt Avgo, the summit. Serpentine rock outcrops and boulders on NNW slope just below the summit. Alt.: 2170 m. 30 Jun 1978. 39 $57^{\prime}$ N, $21^{\circ} 09^{\prime} \mathrm{E}$

19 Lingos Range, about $20 \mathrm{~km}$ NNW of the town of Metsovon, Mt Avgo, N slope. Serpentine boulders in NNE facing scree below the summit. Alt.: 2070 m. 30 Jun $1978.39^{\circ} 57^{\prime} \mathrm{N}, 21^{\circ} 09^{\prime} \mathrm{E}$. 
20 Lingos Range, about $20 \mathrm{~km}$ NNW of the town of Metsovon, Mt Avgo, N slope. Sandstone and quartzite boulders and stones in grassland on $\mathrm{S}$ slope, heavily grazed by sheep and goats. Alt.: 1720 1760 m. 30 Jun, $2 \& 4$ Jul $1978.39^{\circ} 57^{\prime}$ N, $21^{\circ} 09^{\prime}$ E.

21 Lingos Range, about $20 \mathrm{~km}$ NNW of the town of Metsovon, Mt Avgo, NE slope. Outcrops in grassland on W slope, heavily grazed by sheep and goats. Bedrock: a mixture of limestone and

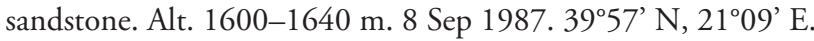

22 Lingos Range, about $20 \mathrm{~km}$ NNW of the town of Metsovon, Mt Avgo, NE slope. W slope with limestone outcrops in grazed grassland. Alt.: 1550-1610 m. 8 Sep $1987.39^{\circ} 57^{\prime} \mathrm{N}, 21^{\circ} 09^{\prime} \mathrm{E}$.

\section{Makedhonia, nomos Florinis}

23 About $15 \mathrm{~km} \mathrm{~S}$ of Lake Mikra Prespa, Mt Triklarion, about 1/1/2 km N of the village of Kristalopigí, about $1 / 2 \mathrm{~km}$ E of the Albanian border. E facing slope with limestone outcrops in grassland heavily grazed by sheep and goats. Alt.: $1410 \mathrm{~m}$. 11 Sep $1987.40^{\circ} 38^{\prime} \mathrm{N}, 21^{\circ} 05^{\prime} \mathrm{E}$.

\section{Makedhonia, nomos Imathía, Vermion Mts}

24 Eparchia Náousis, about $25 \mathrm{~km} \mathrm{NW}$ of the town of Véria, S and E slope of Mt Tsanaktsi. Grassland with scattered thickets of prostrate Juniperus and scattered young Pinus heldreichii on plateau. Schistose limestone and limestone conglomerate. Alt. 1960-2000 m. 13 Sep 1987 \& 29 Apr 1989. 40³7’ N, $21^{\circ} 59^{\prime} \mathrm{E}$.

25 The Vermion massif, the great valley $S$ of Mt Palati. Serpentine outcrops in grassland. Alt.: $1440 \mathrm{~m}$. 12 Sep $1987.40^{\circ} 34^{\prime} \mathrm{N}, 22^{\circ} 09^{\prime} \mathrm{E}$.

26 The Vermion massif, NW of the village of Kato Vermion. Open Pinus nigra-Quercus cerris mixed woodland. Limestone outcrops in grassland in opening in the woodland. Alt.: $1150 \mathrm{~m} .12$ Sep 1987. $40^{\circ} 34^{\prime} \mathrm{N}, 22^{\circ} 02^{\prime} \mathrm{E}$.

\section{Makedhonia, nomos Serron, Vrondous Mts}

27 About $17 \mathrm{~km} \mathrm{~N}$ of the town of Serres, Mt Lailia, SW slope of the summit 'Ali Babas', forest lot II $8 \beta$, at the mountain refuge. Pinus sylvestris woodland, partly of scattered old tall trees, partly of dense thickets of younger 7-8 m tall trees, on SW facing slope. Bedrock: granite. Alt.: 1530-1550 m. 14 Sep 1987. $41^{\circ} 14^{\prime} \mathrm{N}, 23^{\circ} 37^{\prime} \mathrm{E}$.

28 About $17 \mathrm{~km} \mathrm{~N}$ of the town of Serres, Mt Lailia, SW slope of the summit 'Ali Babas', forest lot II 8ß, above the mountain refuge. Granite outcrops in open Pinus sylvestris woodland. Alt.: 1580-1625 m. 14 Sep $1997.41^{\circ} 14^{\prime} \mathrm{N}, 23^{\circ} 37^{\prime}$ E.

\section{Thessalia, nomos Trikalon, North Pindos mountain range}

29 About $10 \mathrm{~km} \mathrm{~S}$ of the town of Metsovon, upper part of Acheloos river valley, about $2 \mathrm{~km} \mathrm{SSE}$ of the village of Chalikion (= Haliki). Quartzite outcrops in grazed grassland on S slope. Alt.: $1200 \mathrm{~m}$. 6 Sep 1987. $39^{\circ} 40^{\prime} \mathrm{N}, 21^{\circ} 13^{\prime} \mathrm{E}$.

\section{Thessalia, nomos Larisis}

30 Mt Ossa, W slope, above the village of Spilia. Abies borisii-regis woodland on W slope. Bedrock: siliceous schist. On soil in opening in the woodland. Alt.: $1230 \mathrm{~m}$. 16 Sep 1987. 3947’ N, 2240’ E. 


\section{List of taxa}

\section{Lichenized fungi}

Acarospora cervina A. Massal.

On sandstone boulder in grassland. (20) GR508. - In Makedhonia known only from Mitikas, Mt Olimbos (Abbott 2009).

Acarospora veronensis A. Massal.

On quartzite and sandstone boulders and stones in grassland. (20) GR446, GR507, GR511, with Caloplaca crenularia GR520. - In Makedhonia known from Florina only (Abbott 2009).

Anaptychia ciliaris (L.) Körb. ex A. Massal.

On E facing vertical marble rock wall, and on twigs of prostrate dwarf-shrub in rock crevice. (1) GR291; (7) GR289. - Two previous finds from Ipiros (Abbott 2009). Aspicilia caesiocinerea (Nyl. ex Malbr.) Arnold

On serpentine boulders and serpentine rock outcrops, on sandstone boulders and pebbles in grassland and on outcrops of siliceous schist. (6) GR537; (8) with Lecidea lapicida var. lapicida GR468; (16) with Rhizocarpon eupetraeoides GR430; (18) GR496; (20) GR509, with Lecanora muralis GR517, with Rhizocarpon macrosporum GR519; (30) with Lecanora bolcana 4519. - Two previous finds from Makedhonia (Abbott 2009).

*** Aspicilia caesiopruinosa (H. Magn.) J.W. Thomson

On serpentine boulders and outcrops, on serpentine stones in scree and on limestone boulders. (6) GR462, GR477, with Umbilicaria cylindrica GR460; (7) GR479; (17) GR504; (18) GR487. - The species grows on calcareous rocks and it is known from northern Scandinavia and Baffin Island (Thomson 1997; Santesson et al. 2004). Its occurrence in the Greek mountains constitute a considerable range extension. Calcicolous lichen species are often found on serpentine (see discussion).

Aspicilia calcarea (L.) Mudd

On limestone rock outcrops, on sandstone boulders and on quartzite outcrops in grassland. (14) 12716; (20) GR455; (29) 4146. - Only two previous records, pre 1900, from Ipiros (Abbott 2009).

*** Aspicilia candida (Anzi) Hue

On vertical marble rock wall. (1) GR464, GR465, GR482, GR484, with Pertusaria albescens GR529. - The species is widespread on calcareous mountain rocks from the Arctic to Central Europe and northern Italy, in North America south to Colorado (Clauzade \& Roux 1985; Thomson 1997; Nimis \& Martellos 2008; Alstrup et al. 2009). Lisicka (2005) reported it from the Slovak Tatra Mts. From the Balkans it has been reported from Bulgaria (Mayrhofer et al. 2005).

Aspicilia cinerea (L.) Körb.

On vertical marble rock wall, on serpentine outcrops and boulders, on serpentine stones and boulders in scree and on quartzite boulders in grassland. (1) with Brodoa intestiniformis GR408; (6) GR421, with Lecanora macrocyclos GR553; (8) GR470, with Lecidea lapicida var. lapicida GR468; (17) GR505, with Aspicilia caesiopruinosa GR504; 
(18) GR486, with Lecidea atrobrunnea GR417; (19) GR414; (20). GR389. - One previous find from Ipiros and four previous finds from Makedhonia (Abbott 2009). Aspicilia contorta (Hoffm.) Körb. subsp. contorta

On quartzite outcrop in grassland. (29) 4145a.

Aspicilia contorta subsp. hoffmanniana S. Ekman \& Fröberg

On quartzite and sandstone boulders and stones in grassland. (20) with Acarospora veronensis GR511.

* Bellemerea cinereorufescens (Ach.) Clauzade \& Roux

On serpentine boulders. (6) with Lecanora polytropa GR386; (8) with Lecidea lapicida var. lapicida GR468. - New to Ipiros. Due to its position far south of the Alps, Abbott (2009) regards the sole previous record (from Peloponnese) doubtful. However, many species with Central European distribution reach the high mountains of Greece (Christensen \& Svane 2009).

* Brodoa intestiniformis (Vill.) Goward

On vertical marble rock wall. (1) GR408. - New to Ipiros. Bryoria fuscescens (Gyeln.) Brodo \& D. Hawksw.

On moss on E side of large granite boulder. (28) 11632, fumarprotocetraric acid by tlc. Bryoria cf. implexa (Hoffm.) Brodo \& D. Hawksw.

On E side of large granite boulder. (28) 11634a, K-, P- or + faintly yellow.

* Buellia aethalea (Ach.) Th. Fr.

On serpentine boulder. (6) GR419, GR434. - New to Ipiros.

Caloplaca crenularia (With.) J.R. Laundon

On serpentine outcrops and boulders and on sandstone boulders, stones and pebbles.

(18) GR420, GR438, GR488, GR495, with Lobothallia radiosa GR410, with Lecidella stigmatea GR493; (20) GR424, GR456, GR520, with Acarospora veronensis GR446, GR511, with Aspicilia calcarea GR455, with Acarospora cervina GR508, with Lecanora polytropa GR516. - Four previous records for Makedhonia (Abbott 2009).

*** Caloplaca festivella ( $\mathrm{Nyl}$.) Kieff.

On serpentine outcrop. (18) GR485. - The species, which mostly occurs on siliceous rocks, is known from Sweden, the Pyrenees and Italy (Santesson et al. 2004, Nimis \& Martellos 2008 - with habitus photo).

Caloplaca flavovirescens (Wulf.) Dalla Torre \& Sarnth.

On serpentine outcrop. (18) GR412, GR490. - In Makedhonia known only from Athos peninsula (Abbott 2009).

* Caloplaca grimmiae (Nyl.) H. Olivier (C. congrediens auct., non (Nyl.) Zahlbr.; C. consociata J. Steiner)

On serpentine boulders. (6) GR618. - An obligate parasite on Candelariella vitellina treated by Poelt \& Doppelbaur (1956). The species occurs scattered in Central and Southern Europe reaching the snow line in the Alps. Also known from Lappland (Poelt 1969). Its distribution was mapped by Poelt \& Kalb (1985). New to Ipiros.

* Caloplaca holocarpa (Hoffm.) A.E. Wade

On outcrops of limestone slate and on sandstone boulders in grassland. (4) with Lecanora muralis GR467; (20) GR513, with Intralichen baccisporus GR515. - New to Ipiros. 
Caloplaca pellodella (Nyl.) Hasse (C. conglomerata (Bagl.) Jatta)

On serpentine boulder in scree. (19) GR500. - C. pellodella is a Mediterranean lichen with a range extending northwards to the warm valleys of the southern Alps' (Poelt 1969). It grows on hard siliceous rock and is never found on calcareous substrates (Buschardt 1979). For the Greek mainland only one record exists: Makedhonia, Mt. Vourinos (Christensen 2000). In Greece it is otherwise known from Kriti and the Agean Islands (Abbott 2009).

*Caloplaca saxicola (Hoffm.) Nordin subsp. saxicola

On limestone outcrop and on Lobothallia radiosa on bird manured top-face of limestone outcrop. (22) 4215; (23) 4370. - New to Makedhonia.

*Caloplaca schistidii (Anzi) Zahlbr.

On moss on marble rock wall and on moss on limestone outcrops and boulders. (1) GR449; (15) 4291, 4293; (21) 4211; (22) 4209, 4214; (23) 4366, 4367, 4368. - New to Ipiros. Three previous records for Makedhonia, all from Mt Olimbos (Abbott 2009). On morphological and molecular grounds Gaya (2009) transferred the species back to the genus Caloplaca from Fulgensia (F. schistidii (Anzi) Poelt).

${ }^{* * *}$ Caloplaca schoeferi Poelt

On moss on serpentine outcrops and boulders. (6) GR299; (25) 4397. - On Grimmia, Schistidium and other mosses on lime-rich rocks in the Alpine zone of the Alps and the Carpathian mountains (Poelt 1969). Recently reported from Macedonia (Mayrhofer et al 2012 - as cf. schoeferi). This, together with the two present finds at $1440 \mathrm{~m}$ and 2150 $\mathrm{m}$ alt., represent a considerable range extension to the south on the Balkan peninsula. As to calcicolous lichens on serpentine, see the discussion.

${ }^{*}$ Caloplaca stillicidiorum (Vahl) Lynge (C. cerina var. chloroleuca (Sm.) Th. Fr.)

On moss on limestone outcrop and on stems of dead dwarf shrubs on limestone outcrops. (21) 4213; (23) 4364, 4374a, 4375a. - New to Makedhonia.

Candelariella aurella (Hoffm.) Zahlbr.

On serpentine outcrops and boulders and on limestone rock outcrops. (6) with Aspicilia caesiocinerea GR537; (14) 12717; (16) with Psora globifera GR405. - From Makedhonia known from four localities only (Abbott 2009).

** Candelariella plumbea Poelt \& Vězda

On outcrop of limestone slate. (3) GR536. - Known from southern Europe: France, Austria, Slovenia and Roumania (Clauzade \& Roux 1985; Suppan et al. 2000). In Greece known from Kriti only (Abbott 2009).

Candelariella vitellina (Hoffm.) Müll. Arg.

On vertical marble rock wall, on serpentine outcrops and boulders, on Lecanora rupicola and on rock surface on serpentine pebbles, stones and boulders in scree, on quartzite and sandstone boulders and stones, on outcrops of siliceous schist, on quartzite outcrop in grassland and on detritus below prostrate Juniperus. (1) with Sporastatia testudinea GR394; (6) GR418, GR473, with Rhizocarpon geographicum GR435, with Lecanora cenisia GR448; (8) with Lecidea lapicida var. lapicida GR468; (16) GR429; (17) with Rimularia insularis GR422, with Aspicilia caesiopruinosa GR504, with Aspicilia cinerea GR505; (18) with Caloplaca crenularia GR420, Lecidea atrobrunnea GR417; (19) 
GR413; (20) GR257, with Caloplaca crenularia GR424, with Acarospora veronensis GR507, with Lecidea fuscoatra GR510, with Lecanora bolcana GR518, with Rhizocarpon macrosporum GR519, with Lobothallia praeradiosa GR522; (24) with Cladonia pocillum 4422; (29) with Aspicilia calcarea 4146; (30) with Lecanora bolcana 4519.

Catillaria chalybeia (Borrer) A. Massal.

On vertical marble rock wall. (1) with Rhizoplaca melanophthalma GR524. - One previous find from Ipiros (Christensen 1994).

Cetraria aculeata (Schreb.) Fr. (Coelocaulon aculeatum (Schreb.) Link)

On soil in grassland and on moss on E side of large granite boulder. (24) 6017; (28) 11623.

Cetraria islandica (L.) Ach.

On the ground among boulders, on soil in grassland and on $\mathrm{E}$ side of large granite boulder. (24) 4417, 6017a; (28) 11626.

*** Cladonia borealis S. Stenroos

On sun-exposed granite outcrop. (27) with Cladonia coccifera 4452, det. T. Ahti. Circumpolar in the northern Hemisphere. Also occurring in Central America, northern Andes, southern Chile and the Sub-Antarctic islands (Stenroos 1989). In Europe known from Fennoscandia, NW Russia, the British Isles, the NW European plain, the Tatra Mts and the Alps (Stenroos 1989: Fig. 2). It has not previously been reported from the Balkans.

** Cladonia cariosa (Ach.) Spreng.

On the ground and below boulder in boulder and stone field. (20) GR237, det. T. Ahti; (21) 4265.

Cladonia chlorophaea (Flk. ex Sommerf.) Spreng.

On mosses on the ground over limestone, on mosses on the ground below serpentine boulder and on litter among serpentine rocks. (2) GR244, fumarprotocetraric acid by tlc, conf. T. Ahti; (6), GR379, det. T. Ahti; (18) GR235, unknown and fumarprotocetraric acid by tlc, det. T. Ahti; (20) GR236, unknown and fumarprotocetraric acid by tlc, det. T. Ahti.

*** Cladonia coccifera (L.) Willd.

On sun-exposed granite outcrop. (27) 4452, conf. T. Ahti. - In Europe known from Fennoscandia and the Alps (Stenroos 1989: Fig. 3A) and from Bulgaria (Mayrhofer et al. 2005).

Cladonia coniocraea (Flörke) Spreng.

On E side of large granite boulder. (28) 11633, fumarprotocetraric acid by tlc, conf. T. Ahti.

Cladonia convoluta (Lam.) P. Cout.

On the ground. (26) 4392.

Cladonia cyathomorpha Stirt. ex Walt. Watson

Among moss on the ground and on moss on limestone outcrop. (12) 10705; (24) 6023, conf. T. Ahti. - C. cyathomorpha is an euoceanic species of the western fringe of Europe not to be expected in Greece (T. Ahti pers. com.). Its occurrence as far east as Greece may be explained by the high precipitation and frequent fog formation in the high 
mountains of the Pindos region. In Ipiros known from Mt Trapezitsa only (Christensen 1994).

Cladonia fimbriata (L.) Fr.

On sun-exposed granite outcrop and on moss on the ground on siliceous schist. (27) 4446, fumarprotocetraric acid by tlc, conf. T. Ahti; (30) 4516. - For Thessalia previously only recorded from the E slope of Mt Olimbos (Abbott 2009).

Cladonia foliacea (Huds.) Willd.

On shallow soil on limestone outcrops in phrygana and on moss and detritus on the ground on siliceous schist. (13) 3934; (30) 4517. - Not mentioned for Ipiros by Abbott (2009) but recorded for that province by Steiner (1894 - as C. alcicornis Flörke). Two previous records for Thessalia.

* Cladonia furcata (Huds.) Schrad.

On shallow soil on limestone outcrops in phrygana. (13) with Cladonia foliacea 3934. - New to Ipiros.

* Cladonia humilis (With.) J.R. Laundon

On the ground below serpentine boulder. (6) GR287, fumarprotocetraric acid by tlc, det. T. Ahti. - New to Ipiros.

Cladonia monomorpha Aptroot, Sipman \& van Herk (C. pyxidata var. neglecta (Flörke) Schaer.)

On shallow soil and moss on limestone outcrops, on moss below slightly overhanging rock of granite outcrop, on a vertical SSW facing granite rock wall. (15) 4295, atranorin and fumarprotocetraric acid by tlc, det. T. Ahti; (23) 4372; (26) with Cladonia pocillum 4388; (27) 4453; (28) 11618, det. T. Ahti; (30) with Cladonia fimbriata 4516. - This species is hitherto recorded from acidic sand dunes and from moss on acidic rock (Aptroot et al. 2001). On loc. 27, 28 and 30 it was found in acidic environments, while at loc. 15, 23 and 26 it was found on moss on limestone outcrops. C. monomorpha has been reported from Makedhonia as C. pyxidata var. neglecta (Abbott 2009). Some earlier records of $C$. pyxidata may refer to this species.

*Cladonia pocillum (Ach.) Grognot

On shallow soil and mosses on frost damaged outcrop of limestone slate, on moss on limestone boulders and outcrops, on moss on the ground among limestone boulders and on detritus below prostrate Juniperus. (3) GR294, fumarprotocetraric acid by tlc, conf. T. Ahti, GR253, conf. T. Ahti; (23) 4362, 4363; (24) 4422; (26) 4388. - New to Ipiros.

Cladonia rangiformis Hoffm.

On moss on limestone outcrop. (26) 4389.

* Cladonia symphycarpa (Flörke) Fr.

On soil below serpentine rock outcrop facing $\mathrm{N}$, on shallow soil and moss on limestone outcrop, on soil and moss between limestone boulders, on detritus on the ground above limestone and on soil in opening in Juniperus thicket. (10) GR240, atranoric and norstictic acids by tlc, conf. T. Ahti; (11) GR 238, conf. T. Ahti; (15) 4294, atranorin and norstictic acid by tlc, conf. T. Ahti; (23) 4374; (24) 4418, atranorin and norstictic 
acid by tlc, conf. T. Ahti, 6018; (26) 4391. - New to Ipiros. Three previous records for Makedhonia.

Collema auriforme (With.) Coppins \& J.R. Laundon

On moss on marble rock wall and among moss and on shallow soil on limestone outcrops in phrygana. (1) with Caloplaca schistidii GR449; (12) 10707a; (13) with Squamarina gypsacea 3936. - One previous record for Ipiros near Metsovon (Christensen \& Svane 2009).

Collema cristatum (L.) F. H. Wigg.

On moss on limestone outcrop. (26) with Cladonia pocillum 4388.

*** Collema glebulentum (Cromb.) Degel.

On limestone boulder. (7) with Toninia candida GR461. - This Arctic-Alpine species has its centre of distribution in Greenland, Iceland, the Fennoscandian area and the British Isles. In Central Europe it is known from Silesia (SW Poland), Czech Republic, Germany, France (the Pyrenees), the Swiss Alps (Degelius 1954, 1974) and Slovakia (Lisická 2005). This Greek find constitutes a considerable range extension to the south east. The specimen was found at sub-alpine conditions at $2150 \mathrm{~m}$ on a group of metamorphosed limestone boulders on the serpentine mountain Smolikas.

* Collema polycarpon Hoffm.

On limestone boulder. (7) with Toninia candida GR461. - New to Ipiros. Collema tenax (Sw.) Ach.

Among moss on the ground and on moss on limestone boulder. (12) 10708; (23) with Caloplaca schistidii 4367. Collema undulatum var. granulosum Degel.

On moss on limestone boulder. (15) 4291a. - In Greece previously only known from Mt Olimbos, Makedhonia, and the Aegean island Evvia (Abbott 2009).

*** Cornicularia normoerica (Gunn.) Du Rietz

On top-face of sun-exposed granite outcrop and on E side of large granite boulder. (27) 4447, 4451; (28) 11630, 11631. - The European distribution of C. normoerica was mapped by Kärnefelt (1986). The general trend is western European oceanic. In the Balkans it is known from Montenegro, Macedonia and Bulgaria (Kärnefelt 1986; Mayrhofer et al. 2005; Knežević \& Mayrhofer 2009). The present finds are from the Vrondous Mts north of the town of Serres, not far from the Bulgarian border.

*** Dermatocarpon intestiniforme (Körb.) Hasse

On a serpentine outcrop on W slope at rivulet. (8) GR251. - This species is found in the Boreal and Alpine climate zones, mainly close to the ground on marly limestones. In the Alps particularly in the Alpine zone (Poelt 1969). At loc. 8 it was found in a subalpine grassland at $2150 \mathrm{~m}$ alt. Also known from Montenegro (Knežević \& Mayrhofer 2009). Dermatocarpon miniatum (L.) W. Mann var. miniatum

On E side of large granite boulder. (28) 11627a.

**Dermatocarpon miniatum var. cirsodes (Ach.) Zahlbr.

Among moss on limestone rock outcrop. (12) 10707. - Known from the island of Tinos (Abbott 2009).

Diploschistes muscorum (Scop.) R. Sant. 
On moss on limestone outcrop. (23) 4371. - One previous record for Makedhonia (Christensen \& Svane 2009).

Diploschistes scruposus (Schreb.) Norman

On vertical marble rock wall. (1) GR384. - One previous find from Ipiros (Christensen \& Svane 2009).

Diplotomma epipolium (Ach.) Arnold

On limestone boulder in sub-alpine grassland. (7) GR452, GR453. - In Ipiros known only from Mt Peristeri (Abbott 2009).

** Fulgensia bracteata (Hoffm.) Räsänen

On soil on vertical marble rock wall. (1) GR398. - According to Abbott (2009) this species is not to be expected south of the Alps, though records exist from the isles of Kriti and Naxos. It is also reported from Montenegro (Knežević \& Mayrhofer 2009). The present find in the high mountains of the Grammos range at the border region to Albania is in accordance with the general ecology of the species (Poelt \& Vězda 1977).

Fulgensia fulgens (Sw.) Elenkin

On vertical limestone rock wall. (1) GR409. - One previous find from Ipiros (Abbott 2009).

*** Ionaspis ceracea (Arnold) Hafellner \& Türk (Hymenelia ceracea (Arnold) Poelt \& Vèzda) On sandstone pebble in grassland. (20) GR512. - A pioneer species on pebbles and close to the ground on boulders, probably widely distributed from the nemoral to the Alpine zones, to the south reaching the Mediterranean area (Poelt \& Vězda 1981).

Lasallia pustulata (L.) Mérat

On sun-exposed granite outcrop, on a vertical SSW facing granite rock wall and on E side of large granite boulder. (27) 4442; (28) 11615, 11624.

*** Lecanora atromarginata (H. Magn.) Hertel \& Rambold

On vertical marble rock wall. (1) with Aspicilia candida GR464, with Rhizocarpon geminatum GR466, with Rhizoplaca melanophthalma GR524. - This is a widespread and common bipolar Arctic-Alpine species (Smith et al. 2009).

* Lecanora bolcana (Pollini) Poelt (L. muralis subsp. bolcana (Pollini) Clauzade \& Roux)

On quartz inclusion on vertical marble rock wall, on serpentine boulders and serpentine outcrops, on sandstone boulders and quartzite outcrops in grassland and on outcrops of siliceous schist. (1) GR440; (6) with Buellia aethalea GR434; (11) GR248; (20) GR518; (29) with Aspicilia calcarea 4146; (30) 4519. - New to Ipiros and Thessalia.

Lecanora cenisia Ach.

On serpentine boulders. (6) GR448. - One previous record for Ipiros (Christensen \& Svane 2009).

** Lecanora cf. configurata $\mathrm{Nyl}$.

On limestone boulder. (7) GR471.

Lecanora dispersa (Pers.) Flörke

On vertical marble rock wall. (1) GR531. - Only one record from the late 19th century exists for Ipiros (Abbott 2009).

*** Lecanora epibryon (Ach.) Ach. 
On soil on vertical marble rock wall. (1) with Megaspora verrucosa GR407. - On moss and litter on lime-rich substrates in the Arctic and Alpine zones (Poelt 1969). It occurs above the tree line in the Arctic, Northern Europe, the Alps and Italy (Poelt \& Vězda 1981; Nimis \& Martellos 2008). It is, however, also known from Montenegro (Knežević \& Mayrhofer 2009), Bulgaria (Mayrhofer et al. 2005) and Macedonia (Mayrhofer et al. 2012).

*** Lecanora formosa (Bagl. \& Carestia) Knoph \& Leuckert

On vertical marble rock wall. (1) GR525. - On steep or overhanging faces of limedeficient rocks in the Alps, Sudeten, Böhmerwald, the Scandinavian mountains, Scotland and the Arctic, occurring in the Alpine to the niveal zones (Poelt \& Vèzda 1981). The 'marble' rock of loc. 1 may, in fact, be a calc-silicate rock (see discussion).

*** Lecanora macrocyclos (H. Magn.) Degel.

On serpentine boulders. (6) GR553. - Known from Fennoscandia, Hungary and Italy (Poelt \& Vězda 1977, Nimis \& Martellos 2008). It is, however, also known from the Iberian Peninsula (Spain, provincia de Madrid, Sierra de Guadarrama, Christensen 13413). The species is probably more widely distributed and overlooked.

* Lecanora marginata (Schaer.) Hertel \& Rambold

On serpentine boulder. (6) GR526. - New to Ipiros.

Lecanora muralis (Schreb.) Rabenh. subsp. muralis

On outcrop of limestone slate, on serpentine boulders and outcrops, on serpentine boulders and pebbles in scree and on quartzite and sandstone boulders and pebbles in grassland. (4) GR467; (6) GR425; (11) GR247, GR252; (17) GR403; (19) with Caloplaca pellodella GR500; (20) GR517, with Acarospora veronensis GR446, with Acarospora cervina GR508; (29) 4147.

* Lecanora polytropa (Hoffm.) Rabenh.

On serpentine outcrops and boulders, on quartzite and sandstone boulders, stones and pebbles in grassland. (6) GR386, GR390, GR436, GR442, with Lecanora rupicola GR447; (18) GR498, with Lecidella stigmatea GR493; (20) GR516, with Lecidella stigmatea GR392, with Acarospora veronensis GR446, GR507, with Caloplaca crenularia GR456, with Acarospora cervina GR508, with Caloplaca holocarpa GR513, with Lecanora muralis GR517, with Lecanora bolcana GR518. - New to Ipiros.

* Lecanora rupicola (L.) Zahlbr. var. rupicola

On quartz excretion on vertical marble rock wall, on serpentine outcrops and boulders and on serpentine boulders and pebbles in scree. (1) GR396, with Sporastatia testudinea GR394, with Lecanora bolcana GR440; (6) GR383, GR441, GR447, with Lecanora polytropa GR386, with Buellia aethalea GR434, with Rinodina guzzinii GR450; (16) GR432; (17) GR404, with Lecanora muralis GR403, with Rimularia insularis GR422; (18) with Lecidea atrobrunnea GR417; (19) GR415. - Var. rupicola is new to Ipiros and Makedhonia.

* Lecanora semipallida H. Magn.

On limestone rock outcrop. (14) 12718. - Two previous records from Kriti and Pelopponisos (Abbott 2009). New to Ipiros.

Lecidea atrobrunnea (DC.) Schaer. 
On serpentine outcrops and boulders. (8) GR476, with Lecidella asema GR475; (10) with Lecidella stigmatea GR469; (18) GR417.

Lecidea fuscoatra (L.) Ach.

On sandstone boulder in grass heath. (20) GR510.

* Lecidea lapicida (Ach.) Ach. var. lapicida

On serpentine boulders and on serpentine stones in scree. (8) GR468, GR478; (17) with Aspicilia cinerea GR505. - New to Ipiros.

Lecidea lapicida var. pantherina Ach. (L. lactea Flörke ex Schaer.)

On limestone boulders and on serpentine rock outcrops. (7) GR463; (16) with Tephromela atra GR431.

*** Lecidea paupercula Th. Fr.

On vertical marble rock wall and on serpentine boulder in scree. (1) GR483; (19) GR499. - This is an Arctic-Alpine species. Its distribution is unclear as it is often included in L. praenubila $\mathrm{Nyl}$.

Lecidea tessellata Flörke

On vertical marble rock wall. (1) with Rhizoplaca melanophthalma GR524. - One previous find from Ipiros (Abbott 2009).

* Lecidella asema (Nyl.) Knoph \& Hertel var. asema

On serpentine boulder. (8) GR475. - Known from a number of Aegean islands. From the mainland only known from Peloponnisos (Abbott 2009). New to Ipiros.

Lecidella carpathica Körb.

On serpentine outcrops and on sandstone stones and pebbles in grassland. (18) GR489, GR497; (20) GR514, with Intralichen baccisporus GR515.

Lecidella stigmatea (Ach.) Hertel \& Leuckert

On serpentine outcrops and boulders and on quartzite and sandstone boulders in grassland. (10) GR469; (18) GR491, GR493; (20) GR392, GR501, with Caloplaca crenularia GR424, with Lecidea fuscoatra GR510, with Lecanora bolcana GR518, with Lobothallia praeradiosa GR522.

* Lepraria neglecta ( $\mathrm{Nyl}$.) Lettau s. lat.

On moss on a vertical SSW facing granite rock wall. (28) 11617, atranorin and alectorialic acid by tlc, conf. T. Tønsberg. - New to Makedhonia.

** Lepraria vouauxii (Hue) R.C. Harris

On twigs of dead shrub. (1) GR445, det. T. Tønsberg.

Leptogium gelatinosum (With.) J.R. Laundon

On moss on limestone outcrop. (26) 4389b. - Two previous records for Makedhonia, both from Mt Olimbos (Abbott 2009).

Leptogium massiliense $\mathrm{Nyl}$.

On vertical marble rock wall. (1) with Rinodina dubyana GR523.

*Leptogium pulvinatum (Hoffm.) Otálora var. pulvinatum (L. lichenoides var. pulvinatum (Hoffm.) Zahlbr.)

Among mosses on the ground and on shallow soil and mosses on limestone outcrops and boulders. (12) 10701, 10702, 10704; (13) with Squamarina gypsacea 3936; (21) 
with Caloplaca stillicidiorum 4213; (23) with Caloplaca schistidii 4366, 4367. - New to Ipiros. One previous record for Makedhonia.

Leptogium saturninum (Dicks.) Nyl.

On E side of limestone conglomerate outcrop in grassland. (24) with Xanthoria sorediata 4398. - Only two previous finds from Makedhonia (Abbott 2009).

Leptogium teretiusculum (Wallr.) Arnold

On moss on limestone boulder and on moss below slightly overhanging rock outcrop of granite. (23) with Caloplaca schistidii 4366; (27) with Cladonia monomorpha 4453. One previous record for Makedhonia (Degelius 1956).

* Lobothallia praeradiosa (Nyl.) Hafellner

On sandstone boulder in grassland. (20) GR522. - New to Makedhonia.

Lobothallia radiosa (Hoffm.) Hafellner (Aspicilia radiosa (Hoffm.) Poelt \& Leuckert)

On serpentine outcrops, on serpentine boulders in scree, on quartzite boulders and outcrops in grassland, on limestone outcrops and on bird manured top-face of limestone outcrop. (18) GR410, GR411; (19) GR387, GR391, GR402; (20) GR423; (22) with Caloplaca saxicola 4215; (23) with Caloplaca saxicola 4370; (29) 4143.

* Megaspora verrucosa auct.

On soil on vertical marble rock wall, and on Cladonia pocillum on frost-damaged outcrop of limestone slate. (1) GR407; (3) GR253, atranorin and norstictic acid by tlc, GR254. - New to Ipiros.

Melanelia fuliginosa (Fr. ex Duby) Essl. (Parmelia glabratula subsp. fuliginosa (Fr. ex Duby) J.R. Laundon)

On E side of large granite boulder. (28) $11635 \mathrm{~b}$.

*** Melanelia stygia (L.) Essl.

On serpentine boulder. (6) GR427. - Widely distributed from the Arctic, North Europe to the mountains of Portugal, Italy and the Balkans, mainly above the tree line (Poelt 1969; Poelt \& Vězda 1981; Nimis \& Martellos 2008). Known as far south as Bulgaria (Mayrhofer et al. 2005) and Macedonia (Mayrhofer et al. 2012).

Mycobilimbia tetramera (de Not.) Vitik. et al. (Bacidia fusca (A. Massal.) Du Rietz)

On litter and primary thallus of Cladonia sp. in montane grassland. (21) 4264. Known from Edessa, NW Makedhonia, and from both the Makedhonian and Thessalian slopes of Mt Olimbos (Abbott 2009).

Neofuscelia pulla (Ach.) Essl. (Parmelia pulla Ach.)

On quartzite outcrop. (29) 4145, with Xanthoparmelia conspersa 4144, with Aspicilia calcarea 4146.

* Parmelia ernstiae Feuerer \& A. Thell

On serpentine boulder and on Parmelia omphalodes on E side of large granite boulder. (6) GR282; (28) with Parmelia omphalodes 11627. - New to Ipiros.

*** Parmelia omphalodes Ach.

On E side of large granite boulder. (28) 11627. - In the Balkans this Arctic to South Mediterranean-montane species is known from Roumania (Skult 1987: Figs 1, 2), Montenegro (Knežević \& Mayrhofer 2009) and Bulgaria (Mayrhofer et al. 2005).

Parmelia saxatilis (L.) Ach. 
On E side of large granite boulder. (28) 11635a.

Peltigera canina (L.) Willd.

On moss on the ground. (30) 4515. - Known from three localities in Thessalia. Peltigera monticola Vitik.

Scattered on soil and mosses on the ground and in crevices of limestone boulders and on moss in alpine grassland on serpentine. (7) GR295; (10) GR239; (23) 4365; (26) 4390. - Specimen no. GR295 was determined in 1986 as 'P. ponojensis (?)' by Vitikainen (before the description of $P$. monticola in 1994). The specimen is probably the one $P$. ponojensis recorded for Ipiros by Vitikainen (1994: Fig. 114). Specimen no. GR239 was determined in 1986 as ' $P$. rufescens s. lat.' by Vitikainen (before the description of $P$. monticola in 1994). Two previous records for both Ipiros and Makedhonia.

Peltigera neckeri Hepp ex Müll. Arg.

Below a Juniperus bush (2) GR246, conf. O. Vitikainen. - This specimen is probably the one recorded by Vitikainen (1994: Fig. 107).

Peltigera praetextata (Flörke ex Sommerf.) Zopf

Among moss on the ground. (12) 10703.

Peltigera rufescens (Weiss) Humb.

On moss and soil in crevice in limestone boulders and outcrops, on soil and moss between limestone boulders and on moss in alpine grassland on serpentine. (7) GR290, conf. O. Vitikainen; (10) GR241, conf. O. Vitikainen; (23) 4375, with Cladonia symphycarpia 4374; (24) 4419. - The one record for Ipiros in Vitikainen (1994: Fig. 119) probably represents the specimens from Mt Smolikas (loc. 7 and 10).

Pertusaria albescens var. globulifera (Turner) Poelt

On vertical marble rock wall. (1) GR529.

Phaeophyscia orbicularis (Neck.) Moberg

On moss on limestone outcrop and on sandstone boulder in grassland. (20) with Rhizocarpon macrosporum GR519; (22) 4210.

* Physcia dubia (Hoffm.) Lettau

On a serpentine outcrops and boulders, on sandstone boulder in grassland and on Parmelia omphalodes on E side of large granite boulder. (9) GR250, teretiuscula morphotype; (19) GR255, teretiuscula morphotype; (20) GR521, teretiuscula morphotype; (28) 11627b. - New to Ipiros.

* Placidium lachneum (Ach.) de Lesd.

On shallow soil on vertical marble rock wall. (1) GR481. - New to Ipiros. Placynthium subradiatum (Nyl.) Arnold

On E side of limestone outcrop. (23) 4387.

* Porpidia macrocarpa (DC.) Hertel \& A.J. Schwab

On serpentine boulders. (8) with Aspicilia calcarea GR470. - New to Ipiros.

* Protoblastenia incrustans (DC.) J. Steiner

On vertical marble rock wall. (1) GR480. - New to Ipiros.

* Protoparmelia badia (Hoffm.) Hafellner var. badia 
On vertical marble rock wall, on serpentine boulders in alpine grassland and on quartzite boulder in grassland. (1) GR406; (6) GR385, GR437; (10) GR249; (18) GR400; (19) GR256; (20) GR388. - New to Makedhonia.

* Psora decipiens (Hedw.) Hoffm.

On shallow soil on frost-damaged outcrop of limestone slate and on shallow soil on limestone outcrops in phrygana. (3) GR293; (13) 3935. - New to Ipiros.

*** Psora globifera (Ach.) A. Massal.

In crevice in serpentine rock outcrop and on serpentine boulder in scree. (16) GR405; (19) with Caloplaca pellodella GR500. - The species is circumpolar in the Arctic, extending south to California (Thomson 1997). In Europe it is known from Fennoscandia and the Alps (Poelt \& Vězda 1981). It has recently been reported from Bosnia-Herzegovina (Bilovitz \& Mayrhofer 2011), Montenegro (Knežević \& Mayrhofer 2009) and Macedonia (Mayrhofer et al. 2012). The present find extends its distribution further south.

** Ramalina capitata (Ach.) Nyl.

On serpentine boulder and on top-face of vertical, SSW facing granite rock wall. (6) GR283; (28) 11622.

Ramalina carpatica Körb.

On E side of large granite boulder. (28) 11629. - Only one previous record for Greece (Makedhonia - Abbott 2009).

*** Rhizocarpon eupetraeoides (Nyl.) Blomb. \& Forssell

On serpentine rock outcrop. (16) GR430. - Distributed in the Arctic (Thomson 1997). In Europe known from Novaja Semlja, northern Fennoscandia and Scotland (Poelt \& V̌̌zda 1977). This new find represents a considerable range extension.

*** Rhizocarpon ferax $\mathrm{H}$. Magn.

On serpentine outcrop. (18) with Caloplaca festivella GR485. - Known from the Arctic (Thomson 1997), the Alpine zone in the Scandinavian mountains, the Tatra mountains and the Alps (Poelt \& Vězda 1977). The range extension to the southern Balkans is noticeable.

*** Rhizocarpon furax Poelt \& V. Wirth

On vertical marble rock wall. (1) with Lecanora formosa GR525. - Known from the Alps and Schwarzwald (Poelt \& Vězda 1977). The range extension to the southern Balkans is noticeable.

Rhizocarpon geminatum Körb.

On vertical marble rock wall. (1) GR466, with Aspicilia candida GR464, GR484. Rhizocarpon geographicum (L.) DC.

On siliceous inclusions in vertical marble rock wall, on bird manured limestone boulder, on serpentine rock outcrops and boulders, on serpentine boulders and stones in scree, on quartzite and sandstone boulders in grassland. (1) with Rhizocarpon macrosporum GR381, with Sporastatia testudinea GR394, with Pertusaria albescens var. globulifera GR529; (6) GR426, GR428, GR435, GR472, GR474, with Protoparmelia badia GR385, with Lecanora marginata GR526, with Aspicilia caesiocinerea GR537, with Lecanora macrocyclos GR553; (7) GR380; (8) with Lecidella asema GR475, with Aspicilia 
calcarea GR470; (16) with Rhizocarpon eupetraeoides GR430; (17) GR503; (18) GR492, with Protoparmelia badia GR400, with Lecidea atrobrunnea GR417, with Caloplaca crenularia GR438; (19) GR416; (20) with Protoparmelia badia GR388, with Caloplaca crenularia GR424, with Lecidea fuscoatra GR510, with Lecanora bolcana GR518, with Rhizocarpon macrosporum GR519, with Lobothallia praeradiosa GR522.

Rhizocarpon macrosporum Räs. (R. sphaerosporum Räs.)

On siliceous inclusions in vertical marble rock wall and on quartzite and sandstone boulders. (1) GR381; (20) GR519. - Though treated as separate species in current floras Nimis \& Martellos (2008) regard R. macrosporum and $R$. sphaerosporum as conspecific. New to Makedhonia.

*** Rhizoplaca chrysoleuca (Sm.) Zopf

On vertical marble rock wall and on serpentine boulder. (1) GR397; (6) GR553. On bird perch stones in the Arctic, in the Scandinavian mountains, in the Alps and on Sardinia (Poelt \& Vězda 1977; Nimis \& Martellos 2008). Recently reported from Montenegro (Knežević \& Mayrhofer 2009) and Bulgaria (Mayrhofer et al. 2005). The new finds extend its range further to the south in the Balkans.

*** Rhizoplaca melanophthalma (DC.) Leuckert \& Poelt

On quartz inclusion in vertical marble rock wall and on serpentine boulders. (1) GR301, GR302, GR524; (6) GR288, GR433, with Buellia aethalea GR434. - With several chemical races distributed from the Arctic to the Alps and the southern European mountains (Poelt \& Vězda 1977). In the Balkans known from Bulgaria (Mayrhofer et al. 2005) and Macedonia (Mayrhofer et al. 2012).

Rimularia furvella (Nyl. ex Mudd) Hertel \& Rambold

On Rhizocarpon geographicum on serpentine pebble in scree. (17) with Endococcus exerrans GR506. - This is the second record for Greece (Abbott 2009). The previous find is also from Makedhonia (Christensen \& Svane 2009).

* Rimularia insularis (Nyl.) Rambold \& Hertel

On Lecanora rupicola on vertical marble rock wall and on Lecanora rupicola on serpentine pebble in scree. (1) with Sporastatia testudinea GR394, with Lecanora rupicola GR396;

(17) GR422, with Lecanora rupicola GR404. - New to Ipiros and Makedhonia.

* Rinodina dubyana (Hepp) J. Steiner

On vertical marble rock wall and on limestone boulder in sub-alpine grassland. (1) GR523 with Protoblastenia incrustans GR480; (7) GR451, GR454, GR527. - New to Ipiros.

* Rinodina guzzinii Jatta

On serpentine boulder. (6) GR450. - New to Ipiros.

Rinodina milvina (Wahlenb. ex Ach.) Th. Fr.

On serpentine boulders and on sandstone boulders. (6) with Aspicilia caesiopruinosa GR462; (20) GR548.

Romjularia lurida (Ach.) Timdal (Psora lurida (Ach.) DC.)

On shallow soil on limestone outcrops in phrygana and on moss on limestone boulder. (13) with Squamarina gypsacea 3936; (22) 4212; (23) 4373, with Caloplaca schistidii 
4367. - One previous record for Ipiros (Christensen 1994) and two for Makedhonia (Abbott 2009).

** Seirophora contortuplicata (Ach.) Frödén (Teloschistes contortuplicatus (Ach.) Clauzade \& Rondon)

On $\mathrm{E}$ facing vertical marble rock wall and on $\mathrm{N}$ facing vertical limestone rock wall facing higher rock wall, shaded. (1) GR292, with Rhizoplaca melanophthalma GR524;

(15). 4290. - May be common as it was found on the very two vertical limestone rock walls included in this study.

**Sporastatia polyspora (Nyl.) Grummann

On serpentine boulders in grassland and on serpentine stones in scree. (10) GR401; (17) with Rhizocarpon geographicum GR503. - In Greece known from some NE Aegean islands only (Abbott 2009).

***Sporastatia testudinea (Ach.) A. Massal.

On vertical marble rock wall. (1) GR394, with Lecidea paupercula GR483). - The species is distributed from the Arctic, the North European mountains to the Balkans and Sierra Nevada in Andalusia (Poelt 1969). Recently reported from Montenegro (Knežević \& Mayrhofer 2009), Bulgaria (Mayrhofer et al. 2005) and Macedonia (Mayrhofer et al. 2012). Squamarina cartilaginea (With.) P. James

On shallow soil on limestone and on quartzite outcrops. (2) GR245; (4) GR 296; (29) 4148.

*Squamarina gypsacea (Sm.) Poelt

On shallow soil on limestone outcrops in phrygana. (13) 3936. - New to Ipiros. Tephromela atra (Huds.) Hafellner

On vertical marble rock wall, on serpentine rock outcrops and on serpentine pebbles in scree. (1) GR395; (16) GR431; (17) GR502, with Lecanora muralis GR403, with Rimularia insularis GR422.

Toninia candida (Weber) Th. Fr.

On Collema polycarpon and C. glebulantum on limestone boulder and on Collema spp. on shallow soil on limestone outcrop. (7) GR461; (15) 4292. - T. candida seems to require cyanophilic lichens, especially species of Collema, for establishment (Timdal 1991). In Makedhonia it is known only from Mt Olimbos and Athos peninsula (Abbott 2009).

*Toninia sedifolia (Scop.) Timdal

On moss on soil on vertical marble rock wall and on moss on limestone boulder. (1) GR399; (23) with Caloplaca schistidii 4366. - New to Ipiros.

Umbilicaria crustulosa (Ach.) Lamy var. crustulosa

On sun-exposed granite outcrop, on a vertical SSW facing granite rock wall and on E side of large granite boulder. (27) 4443; (28) 11619, 11625, 11634.

Umbilicaria cylindrica (L.) Delise

On serpentine boulders and rock outcrops, on serpentine stones in scree, on a vertical SSW facing granite rock wall and on E side of large granite boulder. (6) GR284, GR285, GR286, GR460, with Rhizocarpon geographicum GR435, with Lecanora polytropa GR436, with Protoparmelia badia GR437; (10) GR242; (17) GR439; (28) 11619a, 11621,11628 . - Some of the specimens have very few rhizinae. It seems to be related to 
the degree of exposure and may be a result of stress. Only one previous record for Ipiros and Makedhonia, respectively (Abbott 2009).

* Umbilicaria deusta (L.) Baumg.

On a vertical SSW facing granite rock wall. (28) 11620. - New to Makedhonia.

*** Umbilicaria nylanderiana (Zahlbr.) H. Magn.

On E side of large granite boulder. (28) 11635. - U. nylanderiana is known from Fennoscandia, the Hartz in Germany, the Riesengebierge (Karkonosze) on the border between Poland and the Czech Republic, the Alps, the Pyrenees, Sardinia, Sicily, Carpathian mountains, Macedonia and Kaukasus (Hasselrot 1941; Poelt \& Vèzda 1981; Nimis \& Martellos 2008). Also known from Greenland (Alstrup et al. 2009) and Iceland (Alstrup unpublished).

Verrucaria muralis Ach.

On schistose rock (clay shale?) in $\mathrm{N}$ facing road cutting. (5) 10831.

Xanthoparmelia conspersa (Ehrh. ex Ach.) Hale (Parmelia conspersa (Ehrh. ex Ach.) Ach.)

On E side of large granite boulder and on quartzite outcrops. (28) 11633a; (29) 4144, 4149.

Xanthoparmelia stenophylla (Ach.) Ahti \& D. Hawksw. (Parmelia tararctica Kremp.)

On sun-exposed granite outcrop. (27) 4444, 4445.

Xanthoria elegans (Link) Th. Fr.

On moss and marble outcrops, on limestone boulder and on a serpentine boulder. (1)

GR300, with Rhizocarpon geminatum GR466, with Pertusaria albescens var. globulifera GR529; (7) GR297, GR298; (10) GR243. - Only one previous record for Ipiros (Abbott 2009).

*Xanthoria sorediata (Vain.) Poelt

On E side of limestone conglomerate outcrop in grassland. (24) 4398. - New to Makedhonia.

\section{Non-lichenized lichenicolous fungi}

* Cercidospora epipolytropa (Mudd) Arnold

On Lecanora polytropa on serpentine boulder. (6) with Lecanora polytropa GR386. New to Ipiros.

*** Endococcus exerrans $\mathrm{Nyl}$.

Parasitic on Rhizocarpon geographicum on serpentine pebble in scree. (17) GR506. - The species seems to be an obligate parasite on Rhizocarpon spp. Due to confusion with other species its distribution is badly known. Reliable records exist from Scotland and Sweden (Santesson et al. 2004).

*** Intralichen baccisporus D. Hawksw. \& M.S. Cole

Parasitic on Caloplaca holocarpa on sandstone pebble in grassland. (20) GR515. - This hyphomycete is probably restricted to Caloplaca spp. It was recently described from USA (Nebraska) by Hawksworth \& Cole (2002). It is known from several Central European countries and Turkey and is probably widespread.

Stigmidium sp.

On Psora globifera in crevice in serpentine rock outcrop. (16) with Psora globifera GR405. 


\section{Discussion}

In Table 1 the taxa new to Greece are listed together with their European distribution patterns. It appears that the large majority have Arctic (or Boreal) to Alpine or to Central European-montane or Mediterranean-montane distribution patterns. Recently Christensen \& Svane (2009) also reported a considerably number of taxa with central European and northern European distribution as new to Greece. The relatively large number of taxa with central European and northern European distribution found in the high mountains of northern Greece may indicate the presence of refugia somewhere in the southern Balkans during the last glaciation and subsequent spreading of the lichens to the north following the retreat of the icecap.

In the Greek mainland outcrops of granite are rare. The main occurrence is in the Vrondous Mts north of the Makedhonian town of Serres. On granite rock surfaces (loc. 27 and 28) only macrolichens were collected. The following species were found: Bryoria cf. implexa, Cornicularia normoerica, Dermatocarpon miniatum, Lasallia pustulata, Melanelia fuliginosa, Parmelia ernstii, P. omphalodes, P. saxatilis, Physcia dubia, Ramalina capitata, $R$. carpatica, Umbilicaria crustulosa, U. cylindrica, U. deusta, U. nylanderiana, Xanthoparmelia conspersa and X. stenophylla. With exception of Parmelia ernstii, Ramalina capitata and Umbilicaria cylindrica these species were only recorded from granite. It is noteworthy that the Umbilicariaceae are represented on granite with five species. Only $U$. cylindrica is common throughout the mountains of the Greek mainland, occurring on serpentine outcrops. Bryoria fuscescens, Cetraria aculeata, C. islandica, Lepraria neglecta and Leptogium teretiusculum grew on bryophytes on granite outcrops. Cladonia borealis, C. coccifera, C. coniocraea, C. fimbriata and C. monomorpha were found on the ground in connection with granite outcrops. C. fimbriata and C. monomorpha occur, however, also in areas with other types of bedrock. The majority of the species on granite have northern affinities (Wirth 1980).

In contrast to the rare acid plutonic granite, the ultrabasic plutonic serpentine occurs in many places in Greece. Despite this fact only two papers deal with lichens on serpentine in Greece. Zahlbruckner (1907) reports 19 species from serpentine on the central Aegean island of Tinos and Krause \& Klement (1962) studied the lichen vegetation on serpentine on the west Aegean island of Evvia. One characteristic feature of serpentine is the co-occurrence of silicicolous and calcicolous lichen species (Favero-Longo et al. 2004; Rajakaruna et al. 2012). The lichen flora and vegetation on serpentine or other ophiolithic rocks in the mountains of the Pindos range has never been studied. It, therefore, seems appropriate to publish floristic inventories of a few localities in order to give an impression of the communities present. The summit areas of the two serpentine mountains Smolikas (loc. $10 \& 11$ ) and Augo (loc. $18 \& 19)$ at $2400-2650 \mathrm{~m}$ and $2070-2170 \mathrm{~m}$, respectively, are characterized by serpentine boulders and outcrops in alpine-subalpine grasslands. The following species were found: Aspicilia caesiocinerea (loc. 18), A. cinerea $(18,19)$, Caloplaca pellodella (19), C. crenularia (18), C. festivella (18), C. flavovirescens (18), Candelariella vitellina (18, 19), Lecanora bolcana (11), L. muralis (11, 19), L. polytropa (18), L. rupicola (18, 19), Lecidea atrobrunnea (18), Lecidella stigmatea (10, 18), Lobothalia radiosa (18, 19), Physcia dubia (19), Protoparmelia badia $(18,19)$, Rhizocarpon ferax (18), R. geographicum $(18,19)$, Sporastatia polyspora (10), 
Table 1. Distribution on vegetation zones and altitude belts in Europe of the species new to Greece

\begin{tabular}{|c|c|c|}
\hline Species & Distribution & Source \\
\hline Aspicilia caesiopruinosa & Baffin Island and N Scandinavia & See species list \\
\hline Aspicilia candida & Arctic to Central Europe & See species list \\
\hline Caloplaca festivella & Sweden & Santesson et al. 2004 \\
\hline Caloplaca schoeferi & $\begin{array}{l}\text { Alpine in the Alps and } \\
\text { Carpathians }\end{array}$ & Poelt 1969 \\
\hline Cladonia borealis & $\operatorname{arct}-\operatorname{mieur}(\mathrm{mo})$ & Wirth 1980 \\
\hline Cladonia coccifera & bor-mieur-med-mo & Wirth 1995 \\
\hline Collema glebulentum & arct-bor(-mieur.h'mo/subalp) & Wirth 1980 \\
\hline Cornicularia normoerica & arct-alp,(subatl) & Wirth 1980 \\
\hline Dermatocarpon intestiniforme & (oro)arctic to (oro)boreal & Goward \& Ahti 1992 \\
\hline Endococcus exerrans & ? & See species list \\
\hline Intralichen baccisporus & Central Europe and Turkey & See species list \\
\hline Ionaspis ceracea & bor-smed & Wirth 1980 \\
\hline Lecanora atromarginata & montane (Europe, Scandinavia) & Smith et al. 2009 \\
\hline Lecanora epibryon & mieur-pralp & Wirth 1995 \\
\hline Lecanora formosa & montane (Europe) & Smith et al. 2009 \\
\hline Lecanora macrocyclos & Insufficiently known & Poelt \& Vezda 1977 \\
\hline Lecidea paupercula & alpine & Smith et al. 2009 \\
\hline Melanelia stygia & arct-h'mo/alp & Wirth 1980 \\
\hline Parmelia omphalodes & arct-smed.mo & Wirth 1980 \\
\hline Psora globifera & $\begin{array}{l}\text { montane (Scandinavia, } \\
\text { C.European mountains) }\end{array}$ & Smith et al. 2009 \\
\hline Rhizocarpon eupetraeoides & arctic-alpine & Smith et al. 2009 \\
\hline Rhizocarpon ferax & arctic-alpine & See species list \\
\hline Rhizocarpon furax & mieur-alp & Wirth 1995 \\
\hline Rhizoplaca chrysoleuca & arct-alp & Wirth 1980 \\
\hline Rhizoplaca melanophthalma & arct-alp & Wirth 1980 \\
\hline Sporastadia testudinea & arct-alp & Wirth 1995 \\
\hline Umbilicaria nylanderiana & bor-alp & Wirth 1980 \\
\hline
\end{tabular}

The abbreviations of Wirth (1980 \& 1995) are as follows:

arct $=$ Arctic $;$ alp $=$ Alpine; bor $=$ Boreal $;$ h' $=$ high $;$ med $=$ Mediterranean; mieur $=$ Central European; $\mathrm{mo}=$ montane; oro = montane, refers to altitude generated climate zones; pralp = montane below the alpine zone; smed = submediterranean; subalp = subalpine; subatl = subatlantic

Umbilicaria cylindrica (10) and Xanthoria elegans (10). On the ground between boulders and outcrops grew Cladonia symphycarpa (10,11), Peltigera monticola (10) and P. rufescens (10). At $2150 \mathrm{~m}$ alt. on the serpentine mountain of Smolikas a mountain lake (Drakolimni) is present surrounded by subalpine grasslands with serpentine boulders and outcrops. On the $\mathrm{N}$ facing slopes facing lake Drakolimni some serpentine boulders were investigated for 
lichens (loc. $6 \& 8$ ). On the rock surface grew Aspicilia caesiocinerea (6, 8), A. caesiopruinosa (6), A. cinerea (6, 8), Bellemerea cinereorufescens (6, 8), Buellia aethalea (6), Caloplaca grimmiae (6), Candelariella aurella (6), C. vitellina (6, 8), Dermatocarpon intestiniforme (8), Lecanora bolcana (6), L. cenisia (6), L. macrocyclos (6), L. marginata (6), L. muralis (6), L. polytropa (6), L. rupicola (6), Lecidea atrobrunnea (8), L. lapicida var. Lapicida (8), Lecidella asema (8), Melanelia stygia (6), Parmelia ernstiae (6), Porpidia macrocarpa (8), Protoparmelia badia (6), Ramalina capitata (6), Rhizocarpon geographicum (6, 8), Rhizoplaca chrysoleuca (6), R. melanophthalma (6), Rinodina guzzinii (6), R. milvina (6) and Umbilicaria cylindrica (6). On moss on the boulders at loc. 6 Caloplaca schoeferi was found, and on the ground on soil and moss below the boulders Cladonia chlorophaea and C. humilis were present. Cercidospora epipolytropa parasitized Lecanora polytropa.

In a literature review on ultramafic rocks in relation to lichens Favero-Longo et al. (2004) listed 250 taxa reported more than once from serpentine. 27 taxa from the Pindos range are not included in their list, viz.: Aspicilia caesiopruinosa, Bellemeria cinereorufescens, Caloplaca festivella, C. flavovirescens, C. grimmiae, C. pellodella, C. schoeferi, Cladonia humilis, Dermatocarpon intestiniforme, Lecanora bolcana, L. macrocyclos, L. marginata, Lecidea lapicida var. pantherina, L. paupercula, Melanelia stygia, Parmelia ernstiae, Peltigera monticola, Psora globifera, Ramalina capitata, Rhizocarpon eupetraeoides, $R$. ferax, Rhizoplaca chrysoleuca, $R$. melanophthalma, Rimularia furvella, Rinodina guzzinii, R. milvina and Sporastatia polyspora. Rhizoplaca melanophthalma has, however, been reported twice and Rinodina milvina once from serpentinite in California (Rajakaruna et al. 2012). The remaining taxa have either not previously been recorded from serpentine or have been recorded only once.

Limestone boulders and outcrops on the serpentine mountain Smolikas also occurred at about $2150 \mathrm{~m}$ around lake Drakolimni. Bird-manured limestone boulders (loc. 7) had the following species: Aspicilia caesiopruinosa, Collema glebulentum, C. polycarpon, Diplotomma epipolium, Lecanora cf. configurata, Lecidea lapicida var. pantherina, Rhizocarpon geographicum, Rinodina dubyana, Toninia candida (on Collema spp.) and Xanthoria elegans. The presense of Lecidea lapicida var. pantherina and Rhizocarpon geographicum may be due to influence from dust from the basic siliceous soil of the serpentine bedrock or the rock may contain siliceous impurities as the rock at loc. 1 (see below).

Two vertical limestone rock walls were investigated. The limestone rock at Mt Grammos (loc. 1) had been metamorphosed to marble or perhaps to a calc-silicate rock developed from impure limestone containing sandy or clayey material, which after metamorphosis are scattered through the calcite matrix (Read \& Watson 1970). The rock at Mt Tampuri (loc. 15) consists of hard limestone. At loc. 1 the rock had inclusions of siliceous material and some calcite pieces collected had a thin siliceous film on the surface. Unexpected species communities were hence encountered. For example, at one rock piece the following species grew: Aspicilia candida (GR529), Pertusaria albescens var. globulifera, Rhizocarpon geographicum and Xanthoria elegans. At the rock walls these species were found: Anaptychia ciliaris (loc. 1), Aspicilia candida (1), A. cinerea (1), Brodoa intestiniformis (1), Caloplaca schistidii (1 \& 15 on moss), Candelariella vitellina (1), Catillaria chalybeia (1), Cladonia monomorpha (15 on soil), C. symphycarpa (15 on soil and moss), Collema auriforme (1 on moss), C. undulatum var. granulosum (15 on moss), Diploschistes scruposus (1), Fulgensia 
bracteata (1 on soil), F. fulgens (1), Lecanora atromarginata (1), L. bolcana (1 on quartz), L. dispersa (1), L. epibryon (1 on soil), L. formosa (1), L. rupicola (1 on quartz), Lecidea paupercula (1), L. tesellata (1), Leptogium massiliense (1), Megaspora verrucosa (1 on soil), Pertusaria albescens var. globifera (1), Placidium lachneum (1 on soil), Protoblastenia incrustans (1), Protoparmelia badia (1), Rhizocarpon furax (1), R. geminatum (1), R. geographicum (1), R. macrosporum (1), Rhizoplaca chrysoleuca (1), R. melanophthalma (1 on quartz), Rimularia insularis (1 on Lecanora rupicola), Rinodina dubyana (1), Seirophora contortuplicatus (1 \& 15), Sporastadia testudinea (1), Tephromela atra (1), Toninia candida (15 on Collema sp.), T. sedifolia (1 on soil and moss) and Xanthoria elegans (1).

Quartzite and sandstone occur as minor outcrops in the mountains. At the serpentine mountain Augo at 1720-1760 m in montane grassland the sandstone outcrops have been partly metamorphosed (loc. 20). Thus, the substrate varied from sandstone through partly metamorphosed sandstone to quartzite. Quartzite and sandstone are therefore treated together. The sandstone may be somewhat lime-rich as indicated by species like, e.g., Acarospora cervina, Lecidella stigmatea and Phaeophyscia orbicularis. On quartzite and sandstone (loc. 20 \& 29) the following species were found: Acarospora cervina (loc. 20), A. veronensis (20), Aspicilia caesiocinerea (20), A. calcarea (20, 29), A. cinerea (20), A. contorta (29), A. contorta subsp. hoffmanniana (20), Caloplaca crenularia (20), Caloplaca holocarpa (infested by Intralichen baccisporus, 20), Candelariella vitellina (20, 29), Ionaspis ceracea (20), Lecanora bolcana (20, 29), L. muralis (20, 29), L. polytropa (20), Lecidea fuscoatra (20), Lecidella carpathica (20), L. stigmatea (20), Lobothallia praeradiosa (20), L. radiosa (20, 29), Neofuscelia pulla (29), Phaeophyscia orbicularis (20), Physcia dubia (20), Protoparmelia badia (20), Rhizocarpon geographicum (20), R. macrosporum (20), Rinodina milvina (20), Squamarina cartilaginea (29) and Xanthoparmelia conspersa (29).

A large number of epilithic and particularly epigeic lichens grow facultatively on bryophytes. Only the few obligately muscicolous lichens reported in the paper will be dealt with, namely Caloplaca schoeferi and C. schistidii. The latter grow on cushions of Schistidium and Grimmia on outcrops of limestone or lime-rich rocks in sun and rain exposed situations in the alpine and subalpine zones (Wirth 1980) and is very common in the mountains of northern Greece. Caloplaca schoeferi has the same ecological requirements, except that it was only found on serpentine rocks. It seems to be less common.

Epigeic lichens do not usually constitute a prominent element in the landscape of the Greek mountains. On the contrary, one often needs to look for them in suitable places. Due to heavy grazing and browsing by herds of sheep and goats, epigeic lichens are mainly found in places inaccessible to these animals. Typical places are below prickly shrubs, in narrow spaces below overhanging parts of rock outcrops and boulders, in rock crevices and on top of large boulders or on ledges on steep outcrops. Though common in maquis and phrygana in the lowland, species like Cladonia rangiformis and C. convoluta are not often encountered in the mountains. The most common epigeic lichens in the mountains are Cladonia chlorophaea, C. pocillum, C. monomorpha and C. symphycarpa. Species of Cetraria are very rare. $C$. aculeata and $C$. islandica were thus only found on two localities in the northern part of Makedhonia. 
Due to the fact that most of the specimens were collected when the first author was a novice in lichenology and that the localities were not investigated thoroughly, we have refrained from making comparisons to other investigations and from drawing any conclusions. However, the findings reported in this paper indicate an interesting and diverse lichen flora and vegetation on rock outcrops of the mountains of northern Greece. A better knowledge of these lichen communities will contribute to the knowledge of Greek as well as European biodiversity, the knowledge of the European distribution of lichen species and enhance the knowledge of the ecology of the species. Further studies are hereby encouraged.

Acknowledgements. We are most grateful to T. Ahti (Helsinki), T. Tønsberg (Bergen) and O. Vitikainen (Helsinki) for revision of specimens, to H. Mayrhofer (Graz) for providing essential reprints and to the two referees for constructive comments.

\section{References}

Abbott, B.F.M. 2009. Checklist of the lichens and lichenicolous fungi of Greece. - Bibliotheca Lichenologica 103: 1-368.

Alstrup, V., Kocourková, J., Kukwa, M., Motiejunaite, J., Brackel, W. von \& Suija, A. 2009. The lichens and lichenicolous fungi of South Greenland. - Folia Cryptogamica Estonica 46: 1-24.

Aptroot, A., Sipman, H.J.M. \& van Herk, C.M. 2001. Cladonia monomorpha, a neglected cup lichen from Europe. - The Lichenologist 33: 271-283. doi: 10.1006/lich.2001.0332

Bilovitz, P.O. \& Mayrhofer, H. 2011. Catalogue of the lichenized and lichenicolous fungi of Bosnia and Herzegovina. - Phyton (Horn, Austria) 51: 1-67.

Buschardt, A. 1979. Zur Flechtenflora der inneralpinen Trockentäler unter besonderer Berücksichtigung des Vinschgaus. - Bibliotheca Lichenologica 10: 1-419.

Christensen, S.N. 1994. Lichens associated with Pinus nigra on Mt Trapezitsa, Epirus, NW Greece. - Acta Botanica Fennica 150: 11-20.

Christensen, S.N. 2000. Lichens from thickets of Buxus, Carpinus and Juniperus on Mt Vourinos, Makedhonia, North Central Greece. - Willdenowia 30: 375-386.

Christensen, S.N. \& Svane, S. 2009. New and noteworthy records of lichenized and lichenicolous fungi for mainland Greece. - Willdenowia 39: 187-198. doi: 10.3372/wi.39.39120

Clauzade, G. \& Roux, C. 1985. Likenoj de okcidenta Eŭropo. Ilustrita determinlibro. - Bulletin de la Société Botanique du Centre-Ouest. Nouvelle série - Numéro Spécial 7: 1-893.

Degelius, G. 1954. The lichen genus Collema in Europe. - Symbolae Botanicae Upsaliensis 13(2): 1-499.

Degelius, G. 1956. Studies in the lichen family Collemataceae. II. On the Collema flora of the mainland of Greece. - Svensk Botanisk Tidskrift 50: 496-512.

Degelius, G. 1974. The lichen genus Collema with special reference to the extra-European species. - Symbolae Botanicae Upsaliensis 20(2): 1-215.

Favero-Longo, S.E., Isocrono, D. \& Piervittori, R. 2004. Lichens and ultramafic rocks: a review. - The Lichenologist 36: 391-404. doi: 10.1017/S0024282904014215 
Gaya, E. 2009. Taxonomical revision of the Caloplaca saxicola group (Teloschistaceae, lichen-forming Ascomycota). - Bibliotheca Lichenologica 101: 1-191.

Goward, T. \& Ahti, T. 1992. Macrolichens and their zonal distribution in Wells Gray Provincial Park and its vicinity, British Columbia, Canada. - Acta Botanica Fennica 147: 1-60.

Hasselrot, T.E. 1941. [Zur Kenntnis der Verbreitung einiger Umbilicariaceen in Fennoskandia]. - Acta Phytogepgraphica Suecica 15: 1-75. (In Swedish)

Hawksworth, D.L. \& Cole, M.S. 2002. Intralichen, a new genus for lichenicolous "Bispora" and "Trimmatostroma" species. - Fungal Diversity 11: 87-97.

Kärnefelt, I. 1986. The genera Bryocaulon, Coelocaulon and Cornicularia and formerly associated taxa. Opera Botanica 86: 1-90.

Knežević, B. \& Mayrhofer, H. 2009. Catalogue of the lichenized and lichenicolous fungi of Montenegro. - Phyton (Horn, Austria) 48(2): 283-328.

Krause, W. \& Klement, O. 1962. Zur Kenntnis der Flora und Vegetation auf Serpentinstandorten des Balkans. 5. Flechten und Flechtengesellschaften auf Nord-Euböa (Griechenland). - Nova Hedwigia 4: 182-262.

Lisická, E. 2005. The lichens of the Tatry Mountains. Slovak Academy of Science, Bratislava.

Mayrhofer, H., Denchev, C.M., Stoykov, D.Y. \& Nikolova, S.O. 2005. Catalogue of the lichenized and lichenicolous fungi in Bulgaria. - Mycologia Balcanica 2: 3-61.

Mayrhofer, H., Malíček, J., Rohrer, A., Svoboda, D. \& Bilovitz, O. 2012. New or otherwise interesting lichenized and lichenicolous fungi from Macedonia. - Fritschiana 71: 1-35.

Nimis, P.L. \& Martellos, S. 2008. ITALIC - The Information System on Italian Lichens. Version 4.0. University of Trieste, Dept. of Biology, IN4.0/1 (http://dbiodbs.univ.trieste.it/).

Poelt, J. 1969. Bestimmungsschlüssel europäischer Flechten. J. Cramer, Vaduz.

Poelt, J. \& Doppelbaur, H. 1956. Über parasitische Flechten. - Planta 46: 467-480. doi: 10.1007/ BF01911154

Poelt, J. \& Kalb, K. 1985. Die Flechte Caloplaca congrediens und ihre Verwandten: Taxonomie, Biologie und Verbreitung. - Flora 176: 129-140.

Poelt, J. \& Vězda, A. 1977. Bestimmungsschlüssel europäischer Flechten. Ergänzungsheft I. J. Cramer, Vaduz.

Poelt, J. \& Vězda, A. 1981. Bestimmungsschlüssel europäischer Flechten. Ergänzungsheft II. J. Cramer, Vaduz.

Rajakaruna, N., Knudsen, K., Fryday, A.M., O’Dell, R.E., Pope, N., Olday, F.C. \& Woolhouse, S. 2012. Investigation of the importance of rock chemistry for saxicolous lichen communities of the New Idria serpentinite mass, San Benito County, California, USA. - The Lichenologist 44: 695-714. doi: $10.1017 /$ S0024282912000205

Read, H.H. \& Watson, J. 1970. Introduction to Geology. Vol. 1. Principles. MacMillan and Co Ltd., London and Basingstoke.

Santesson, R., Moberg, R., Nordin, A., Tønsberg, T. \& Vitikainen, O. 2004. Lichen-forming and lichenicolous fungi of Fennoscandia. Museum of Evolution, Uppsala University.

Skult, H. 1987. The Parmelia omphalodes complex in the Northern Hemisphere. Chemical and morphological aspects. - Annales Botanici Fennici 24: 371-383.

Smith, C.W., Aptroot, A., Coppins, B.J., Fletcher, A., Gilbert, O.L., James, P.W. \& Wolseley, P.A. (eds) 2009. The lichens of Great Britain and Ireland. The British Lichen Society, London. 
Steiner, J. 1894. Flechten. Pp. 262-266 - In: E. v. Halácsy. Botanische Ergebnisse einer im Auftrage der hohen kaiserl. Akademie der Wissenschaften unternommenen Forschungsreise in Griechenland. I. Beitrag zur Flora von Epirus. - Denkschriften der Kaiserlichen Akademie der Wissenschaften, Mathematisch-Naturwissenschaftliche Classe 61: 217-268.

Stenroos, S. 1989. Taxonomy of the Cladonia coccifera group. 1. - Annales Botanici Fennici 26: 157-168.

Suppan, U., Prügger, J. \& Mayrhofer, H. 2000. Catalogue of the lichenized and lichenicolous fungi of Slovenia. - Bibliotheca Lichenologica 76: 1-215.

Timdal, E. 1991. A monograph of the genus Toninia (Lecideaceae, Ascomycetes). - Opera Botanica 110: $1-137$.

Thomson, J.W. 1997. American Arctic lichens 2. The microlichens. University of Wisconsin Press, Madison.

Vitikainen, O. 1994. Taxonomic revision of Peltigera (lichenized Ascomycotina) in Europe. - Acta Botanica Fennica 152: 1-96.

Wirth, V. 1980. Flechtenflora. Verlag Eugen Ulmer, Stuttgart.

Wirth, V. 1995. Die Flechten Baden-Württembergs. Verlag Eugen Ulmer, Stuttgart.

Zahlbruckner, A. 1907. Aufzählung der von Dr. H. Bretzl in Griechenland gesammelten Flechten. Hedwigia 47: 60-65. 